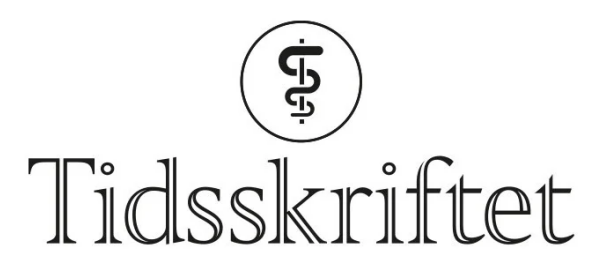

DEN NORSKE LEGEFORENING

\title{
Godkjenning først, forskning etterpå?
}

DEBATT

\section{MYRA HEGRAND}

Myra Hegrand er medisinstudent ved Universitetet i Oslo.

Forfatteren har fylt ut ICMJE-skjemaet og oppgir ingen interessekonflikter.

\section{JENS PAHNKE}

jens.pahnke@medisin.uio.no

Jens Pahnke er dr.med. og dr.rer.nat., europeisk spesialist i nevropatologi (Euro-CNS), professor I ved Universitetet i Oslo og overlege i bistilling ved Oslo universitetssykehus. Han er fagleder for Seksjon for nevropatologi og leder for en translasjonell lab i nevrodegenerasjonsforskning og nevropatologi ved Universitetet i Oslo / Oslo universitetssykehus.

Forfatteren har fylt ut ICMJE-skjemaet og oppgir ingen interessekonflikter.

\section{Nylig fikk en antistoffbehandling mot demens} markedstillatelse i USA uten å ha demonstrert klinisk effekt. Kan dette bane vei for en praksis hvor vi godkjenner først og forsker etterpå?

Legemiddelet aducanumab (Aduhelm ${ }^{\mathrm{TM}}$ ) ble i juni 2021 FDA-godkjent via accelerated approval, som tillater pasientutprøvning av legemidler som fyller et udekket medisinsk behov mot livstruende tilstander (1). Slik godkjenning benytter surrogatendepunkter som har som mål å predikere klinisk effekt, og er fortrinnsvis er brukt i kreftbehandling for små pasientgrupper med fremskreden sykdom (2) $)$. Ved å hurtiggodkjenne en demensbehandling som er aktuell for flere millioner pasienter, har U.S. Food and Drug Administration (FDA) åpnet for et paradigmeskifte i utviklingen av legemidler, hvor omstridte, patofysiologiske biomarkører erstatter kliniske endepunkter. Produktet vil snart kunne være aktuelt for Norge og Europa: Søknad ble sendt til Det europeiske legemiddelbyrået (EMA) i oktober 2020 (3), og det er vist at FDA og EMA ender på samme beslutning i over $90 \%$ av søknadene om markedstillatelse (4.). Hva vil en slik godkjenning kunne medføre i et norsk marked?

\section{Kontroversiell godkjenning}

Alzheimers sykdom er kjennetegnet av senile plakk utenfor nervecellene. Disse består hovedsakelig av proteinet $\beta$-amyloid. Det har imidlertid ikke vært mulig å vise en korrelasjon mellom mengden plakk og kognitiv dysfunksjon, og det er vist at reduksjon av mengden plakk ikke forhindrer videre sykdomsprogrediering (5, 6 ). Det uavhengige, 
rådgivende utvalget for aducanumab var enige om at legemiddelet ikke var antatt å ha klinisk effekt (7.), fordi søknaden baserte seg på en studie der reduksjon av senile plakk ble brukt som surrogatendepunkt for klinisk effekt på kognitiv funksjon. FDA-godkjenningen har derfor skapt stor splid i fagmiljøet (ㅁ).

\section{«En restriktiv legemiddelgodkjenning med fokus på kliniske endepunkter er nødvendig for å sikre at det ikke blir kommersielt gunstig å ta snarveier i utviklingen av legemidler»}

Programmet for raskere godkjenning krever at det gjennomføres en postgodkjenningsstudie, men produsenten har ni år på seg til å gjennomføre dette (9.). I mellomtiden kan staten komme til å bruke omtrent 500 ooo kroner (므, 11 ) årlig per pasient på en behandling som man ikke vet effekten av. Som et av landene i verden med høyest offentlig dekning av helseutgifter (1ㅡ) (86\% i 2020 (13)), vil godkjenning av aducanumab i Norge påvirke helsebudsjettet i stor grad.

\section{Påvirkning av legemiddelmarkedet}

Avgjørelsen kan skape uønsket presedens. Dersom terskelen for godkjenning senkes, vil norske leger måtte holde oversikt over hvilke legemidler som har bevist klinisk effekt og hvilke som kun er under utprøvning. Det vil også kunne påvirke utviklingen av andre legemidler mot samme sykdom, der de som innvilges hurtiggodkjenning, vil ha et forsprang på legemidler der forskningen bruker kliniske endepunkter. I dette aktuelle tilfellet kan aducanumab bremse satsning på andre angrepspunkter mot Alzheimers sykdom. Det er for eksempel vist at induksjon av transportører i blod-hjerne-barrieren som pumper ut $\beta$-amyloid som plakkene består av, er en lovende mekanisme (14.). Det er identifisert rimelige stoffer med denne effekten som dermed kan brukes i forebygging og behandling av Alzheimers sykdom (15,16). At aducanumab kommer på markedet før bevist effekt, vil kunne medføre færre ressurser til forskning på slike angrepspunkter.

Det er behov for bred forskning i utviklingen av legemidler, og utvidet bruk av hurtiggodkjenning kan bidra til at vi overser jevngode behandlingsmuligheter. En restriktiv legemiddelgodkjenning med fokus på kliniske endepunkter er nødvendig for å sikre at det ikke blir kommersielt gunstig å ta snarveier i utviklingen av legemidler.

\section{LITTERATUR}

1. FDA. Accelerated Approval Program. https://www.fda.gov/drugs/information-health-careprofessionals-drugs/accelerated-approval-program Lest 11.8.2021.

2. Mullard A. Controversial Alzheimer's drug approval could affect other diseases. Nature 2021; 595: 162-3. [PubMed][CrossRef]

3. Biogen. European Medicines Agency Accepts Biogen's Aducanumab Marketing Authorization Application for Alzheimer's Disease. https://investors.biogen.com/news-releases/news-releasedetails/european-medicines-agency-accepts-biogens-aducanumab-marketing Lest 13.8.2021.

4. Kashoki M, Hanaizi Z, Yordanova S et al. A comparison of EMA and FDA decisions for new drug marketing applications 2014-2016: Concordance, discordance, and why. Clin Pharmacol Ther 2020; 107: 195-202. [PubMed][CrossRef]

5. Holmes C, Boche D, Wilkinson D et al. Long-term effects of Abeta42 immunisation in Alzheimer's disease: follow-up of a randomised, placebo-controlled phase I trial. Lancet 2008; 372: 216-23. [PubMed][CrossRef]

6. Richard E, den Brok MGHE, van Gool WA. Bayes analysis supports null hypothesis of anti-amyloid beta therapy in Alzheimer's disease. Alzheimers Dement 2021; 17: 1051-5. [PubMed][CrossRef]

7. Alzforum. Aducanumab Approved to Treat Alzheimer's Disease.

https://www.alzforum.org/news/research-news/aducanumab-approved-treat-alzheimers-disease Lest 
28.7.2021.

8. Alzforum. Aducanumab Approval Sparks Backlash. https://www.alzforum.org/news/researchnews/aducanumab-approval-sparks-backlash Lest 19.8.2021.

9. CNBC. Biogen CEO on FDA approval for its Alzheimer's drug.

https://www.cnbc.com/video/2021/o6/o7/biogen-ceo-on-fda-approval-for-its-alzheimers-drug.html Lest 28.7.2021.

10. Biogen. Biogen and Eisai launch multiple initiatives to help patients with Alzheimer's disease access ADUHELM ${ }^{\mathrm{TM}}$. http://media.biogen.com/news-releases/news-release-details/biogen-and-eisailaunch-multiple-initiatives-help-patients Lest 28.7.2021.

11. Norges Bank. Valutakurser. https://www.norges-bank.no/tema/Statistikk/Valutakurser/ Lest 11.8.2021.

12. OECD. Health at a Glance 2019: OECD Indicators. https://read.oecd-ilibrary.org/social-issuesmigration-health/health-at-a-glance-2019_7f66369c-en\#page2 Lest 13.8.2021.

13. Statistisk sentralbyrå. Helseregnskap. https://www.ssb.no/nasjonalregnskap-ogkonjunkturer/nasjonalregnskap/statistikk/helseregnskap Lest 11.8.2021.

14. Pahnke J, Langer O, Krohn M. Alzheimer's and ABC transporters-new opportunities for diagnostics and treatment. Neurobiol Dis 2014; 72: 54-6o. [PubMed][CrossRef]

15. Perloff MD, von Moltke LL, Störmer E et al. Saint John's wort: an in vitro analysis of P-glycoprotein induction due to extended exposure. Br J Pharmacol 2001; 134: 1601-8. [PubMed][CrossRef]

16. Hofrichter J, Krohn M, Schumacher T et al. Reduced Alzheimer's disease pathology by St. John's Wort treatment is independent of hyperforin and facilitated by ABCC 1 and microglia activation in mice. Curr Alzheimer Res 2013; 10: 1057-69. [PubMed][CrossRef]

Publisert: 14. september 2021. Tidsskr Nor Legeforen. DOI:10.4045/tidsskr.21.059o

(C) Tidsskrift for Den norske legeforening 2023. Lastet ned fra tidsskriftet.no 26. april 2023. 